\title{
GIS ANALYSIS OF THE CONSEQUENCES OF SHORT-TERM URBAN PLANNING IN A MASS TOURISM DESTINATION IN SPAIN
}

\author{
J. L. MIRALLES ${ }^{1} \&$ S. GARCÍA-AYLLÓN² \\ ${ }^{1}$ Department of Urban Planning, Polytechnic University of Valencia, Spain. \\ ${ }^{2}$ Department of Civil Engineering, Technical University of Cartagena, Spain.
}

\begin{abstract}
Urban planning is a lengthy and settled process, the results of which usually emerge after several years or even decades. Therefore, for a proper urban design of cities, it is necessary to use parameters that are able to predict and gauge the potential long-term behaviour of urban development.

In the tourist towns of the Mediterranean coast, long-term design is often at odds with the generation of business profits in the short term. This paper presents the results of this phenomenon for an interesting case of a Spanish Mediterranean coastal city created from scratch in the 1960s and turned into a tourist destination, which today is hypertrophied.

La Manga del Mar Menor in the Region of Murcia every year reaches a population of more than 250,000 people during the summer, with only a few thousand in winter. This crowded environment with an asymmetric behaviour submits annual progressive impoverishment in its economic return. This questionable profitability is the result of a misguided urban development, and its results are analysed through the evolution of the land market and the resulting urbanization in the last 50 years using a GIS methodology.

Keywords: La Manga, mass tourism product, Mediterranean coast urban development, retrospective urban analysis, urban GIS analysis.
\end{abstract}

\section{INTRODUCTION: BOUNDARY CONDITIONS OF INITIAL URBANIZATION PROCESS}

To carry out a GIS analysis of an urbanization process over time, the first factor to consider is the initial boundary conditions of the territory. These conditions must cover urban, social and economic factors.

La Manga del Mar Menor is one of the most interesting cases of urban development on the Mediterranean coast. It is an ancient dune ridge located in the Region of Murcia, in south-eastern Spain (Fig. 1). It is, therefore, a singular and unique geographical element in the Mediterranean. Unchanged for many centuries by the hand of man, its special configuration as a natural closure of the Mar Menor lagoon and its two beach lines of $20 \mathrm{~km}$ with unspoiled sand aroused the interest of a visionary developer named Tomas Maestre in the late 1950s (Fig. 2).

To restore the country's battered economy after two decades of autarky and international isolation, the Spanish government initiated a policy of promoting foreign exchange earnings in the early 1960s. This policy was implemented through the enhancement of the coast for mass tourism using the Law of Centres and National Tourist Interest Areas of 1962 (hereinafter LC\&NTIA). This was a tool that allowed an accelerated urbanization of various strategic coastal locations as an exception to the general urban regulation (the Land Act of 1956), with the help and financial backing of the State. The main premise of the law was to create urban infrastructures and quality tourist sites oriented to foreign tourism with a high purchasing power. La Manga was included in a list in the law along with others such as Marbella in Malaga, Son Parc in Baleares, Campoamor and La Zenia in Alicante or Sotogrande in Cadiz [1].

These projects and works, despite their size and public funding, were allocated directly to the private sector, with their management often being in the hands of a single promoter close to the 


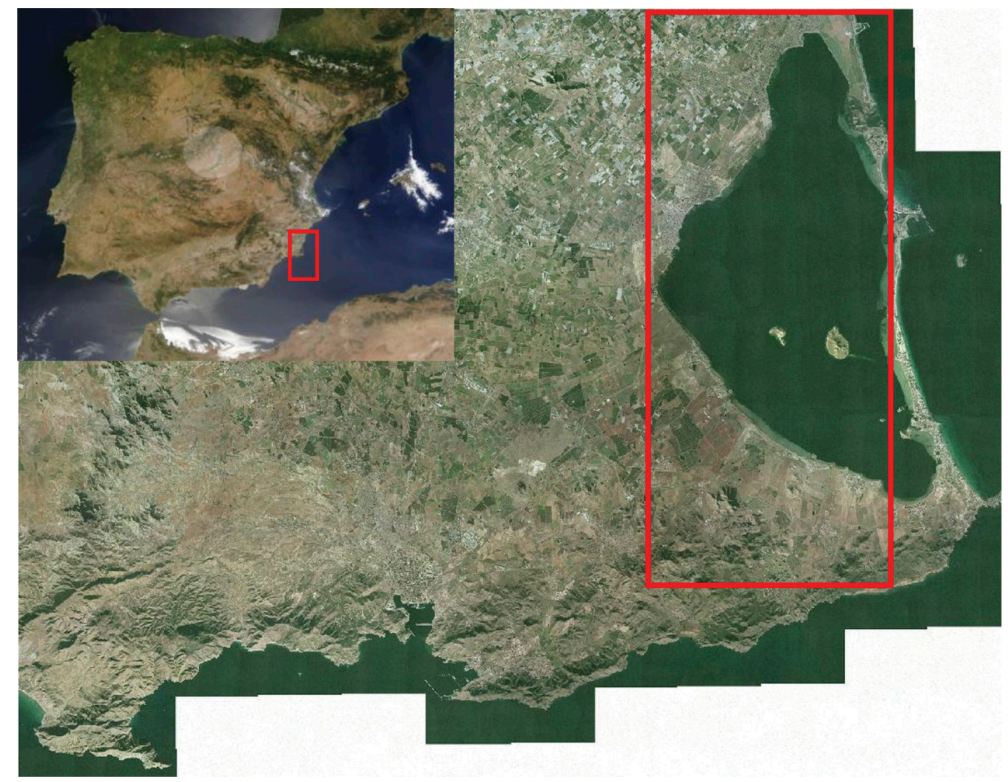

Figure 1: La Manga del Mar Menor today. Source: Cartomur.

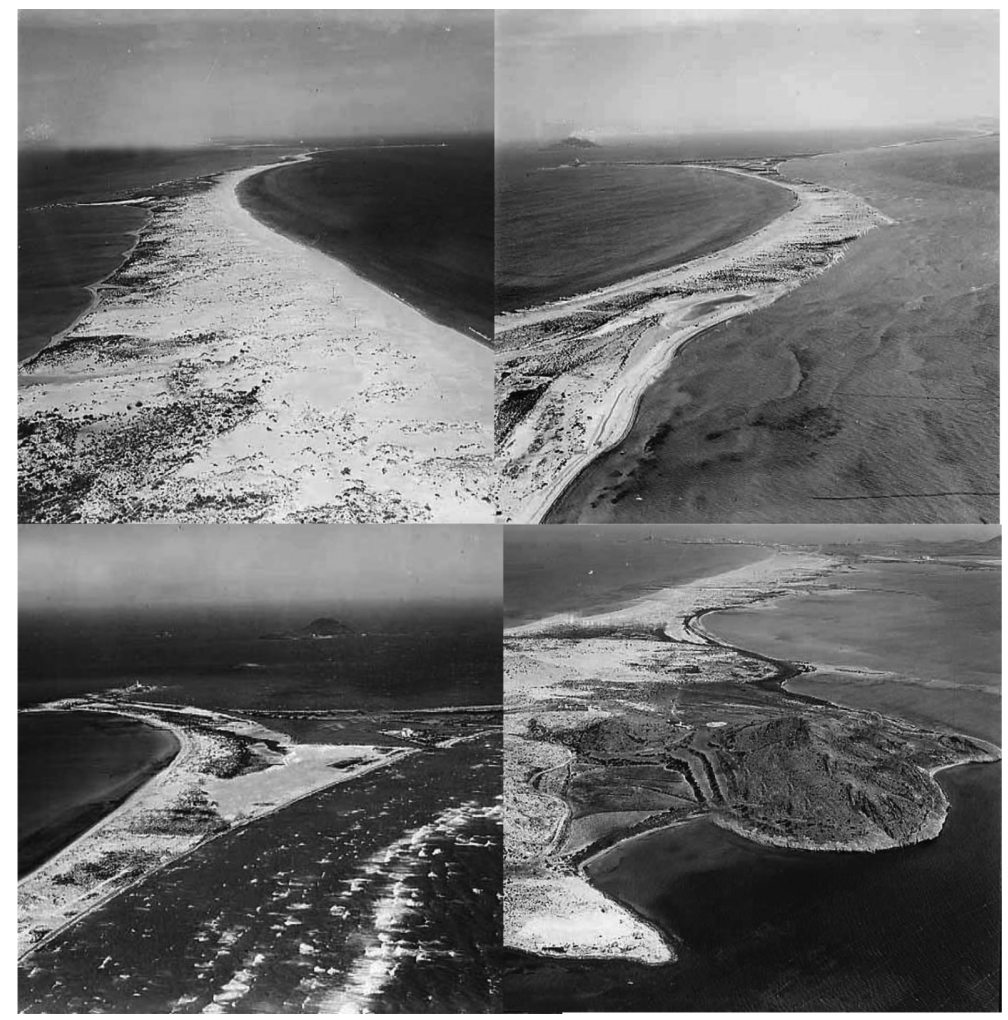

Figure 2: La Manga in the 1950s. Source: Spanish Landscapes, Inc. 
regime (as was the case of the builder of Marbella, José Banús or La Manga with businessman Tomas Maestre). Maestre handed the La Manga masterplan to Antoni Bonet, an internationally renowned architect tanned in projects of this size in South America, such as the masterplan of Buenos Aires or the tourist plan of Punta Ballena in Uruguay (Fig. 3).

The initial project was done according to the principles of quality and sustainability posed by the Act of 1962 with a quite correct urban design. Bonet set a city out of nowhere, designed for a cap on future population of 60,000, with high value-added infrastructure and tourism-oriented services. The urban design and land consumption were governed by the modernist principles of the Charter of Athens in 1933, despite pressure from Maestre. The sustainability of the proceedings and the reasonable use of space generated a structured urban network that toggled a skyline of high and low density. This configuration frees visuals while maintaining the quality of the environment, creates zones with different uses enabling the integration of equipments and public spaces, and implements a reasoned management of urban traffic in a difficult area to administer. The possible seasonality of demand spikes in summer and winter empties was dimmed by 'manufacturing' a city with a stable base population of 15,000 people and summer peaks of 60,000 (Fig. 4).

It was, therefore, a project that, apart from some technical deficiencies, presented a rational urban development model and especially focused on maintaining a long-term equilibrium. The plan is provided for urbanizing the $20 \mathrm{~km}$ of the city with 60,000 people over a period of 30 or 40 years.

The development of the former process of the ancient dunes was done linearly from the south to the north from the early 1960s. This easily built urban structure ran through scheduled planning of Bonet's Plan and the strong financial injection of government investment of more than 11,000 million pesetas divided into four lots (Fig. 5), derived from the subsidy policy of the LC\&NTIA.

This public funding allowed Maestre to create an important corporate network. The sale of plots and building hotels and installations such as marinas, casinos and entertainment centers that funded infrastructure works generated significant capital gains. This urban-economic setting provided with little administrative supervision gave the authorized project managers great discretion to undertake the most important and expensive elements of the plan in just 10 years (Fig. 6).

The elitist environment and economic growth of the 1960s developmentalism placed La Manga as an international tourist destination by promoting classy projects such as casinos, marinas, artificial

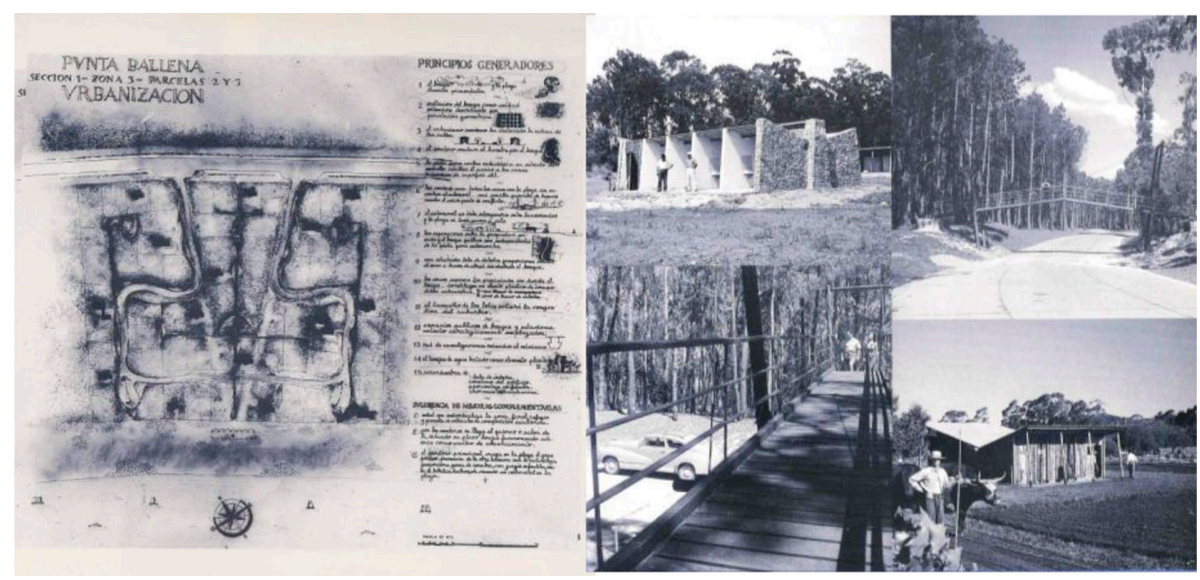

Figure 3: Punta Ballena urbanization (Uruguay). Source: Antonio Bonet Monograph, Ed. 2G (1999). 


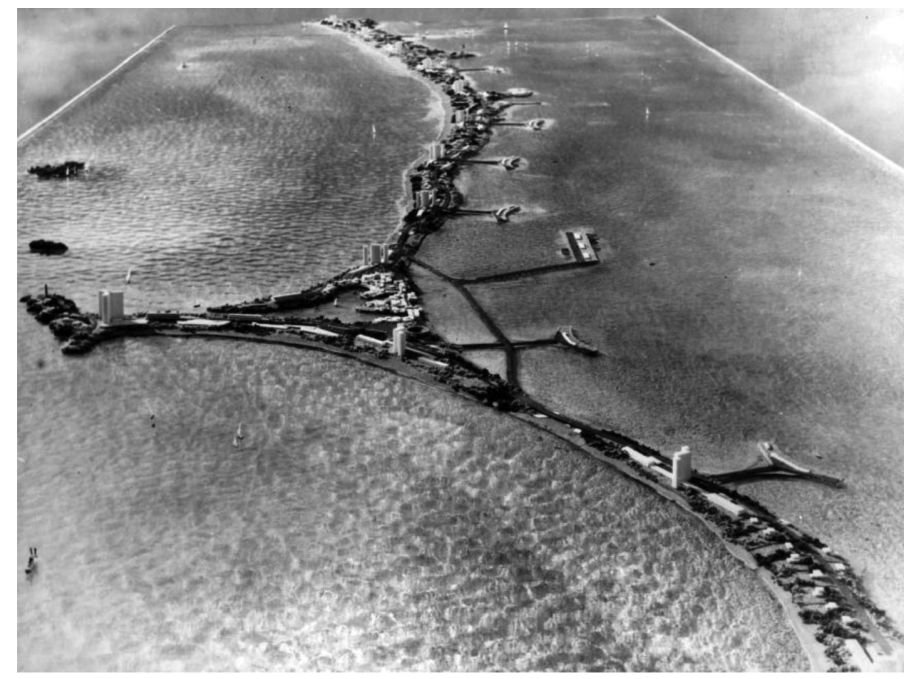

Figure 4: Model of the project presented in 1963 to the minister Manuel Fraga. Source: Jose Parra.

\begin{tabular}{|l|c|c|c|c|}
\hline \multicolumn{1}{|c|}{ Project } & $\begin{array}{c}\text { Approved } \\
\text { date, Official } \\
\text { Gazette }\end{array}$ & $\begin{array}{c}\text { Surface } \\
\text { (ha) }\end{array}$ & $\begin{array}{c}\text { Capacity } \\
\text { (num. inhab) }\end{array}$ & $\begin{array}{c}\text { Public } \\
\text { investment } \\
\text { (M pesetas) }\end{array}$ \\
\hline $\begin{array}{l}\text { La Manga lot in } \\
\text { Cartagena }\end{array}$ & $12-9-1966$ & 88 & 16,920 & 2,200 \\
\hline $\begin{array}{l}\text { La Manga lot in } \\
\text { San Javier }\end{array}$ & $27-1-1969$ & 280 & 36,400 & 8,980 \\
\hline $\begin{array}{l}\text { Honda Beach (La } \\
\text { Manga) }\end{array}$ & $11-2-1967$ & 55 & 4,500 & 296 \\
\hline $\begin{array}{l}\text { Dos Mares lot } \\
\text { (La Manga) }\end{array}$ & $25-2-1969$ & 61 & 1,900 & 47 \\
\hline
\end{tabular}

Figure 5: Approval of public investment in La Manga. Origin: Official State Gazette.

islands, an oceanfront airport and important architectural proposals. The architectural quality of the urban proposal attracted wealthy clients and architects to develop the urban plot with works that strengthened the environmental quality of the city.

The urban plan stratified users into two levels of purchasing power: a mid-level temporary user, staying in hotels and high-density units $3 \mathrm{~m}^{3} / \mathrm{m}^{2}$, and a more exclusive property acquirer of singlefamily parcels with minimum size of 600-2000 $\mathrm{m}^{2}$ that allow urban fluffing between the 12 cores. These residential spaces between cores, according to the spirit of flexibility of the plan, additionally provided some buildability with values around $0.5 \mathrm{~m}^{3} / \mathrm{m}^{2}$ to give greater freedom to designers in development planning. Even so, the preordination of parcels set values close to $0.15 \mathrm{~m}^{3} / \mathrm{m}^{2}$ resulting in the architectural configurations for businessmen, artists and politicians who constituted a great deal of the customers of La Manga (Fig. 7).

\section{ALTERATION OF URBAN DEVELOPMENT MODEL IN STUDY: DISTORTION FACTORS OF THE PROCESS STARTED}

It should be noted that some of the defects that the project of La Manga suffered resided in the extraordinary difficulty of maintaining the structural guidelines of the process over such a long 

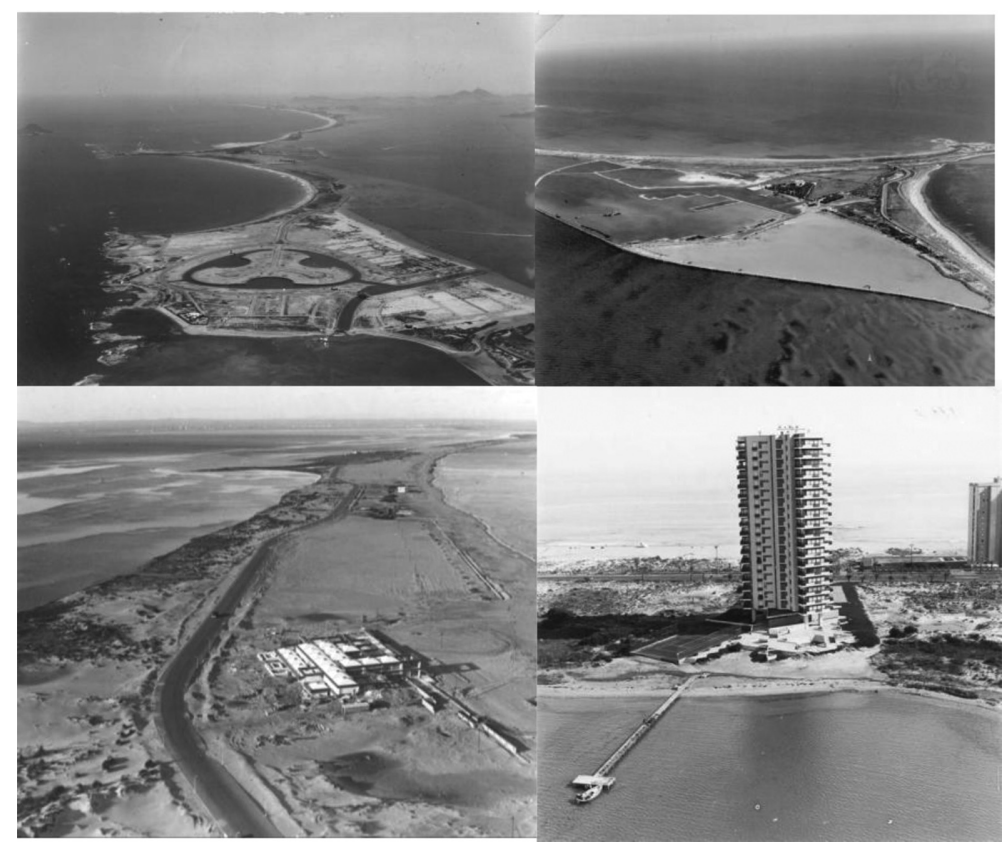

Figure 6: Implementation of the major infrastructures and equipments of La Manga in the late 1970s. Source: [5].

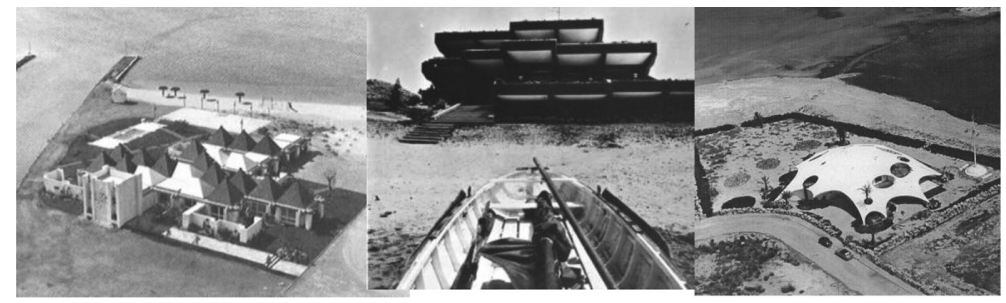

Figure 7: From left to right: Casa Rubio, Huarte and Cotorruelo. Missing mansions of business model of La Manga from the 1960s. Source: Journal COAM.

period of time. The boundary conditions of political, economic and legal projects change, since these features are variable and are subject to changing situations over time.

In the case of Spain, the country experienced a turbulent period in the mid-1970s both economically and politically (and thus also legally). The 1960s developmentalism was truncated in the middle stage of its growth in the 1970s with the two oil crises. In Spain, although the crises took a little longer to arrive, their consequences were as virulent as in the rest of Europe. GDP fell to negative levels while prices and interest rates reached values of 25\% (Fig. 8).

The change in the economic situation quickly moved to coastal urban processes. This rising of financing cost conditions in the states, coupled with the political situation in Spain, was changes which during this time led to the hasty completion of the LC\&NTIA in 1975. This sudden interruption occurring on full development of numerous important tourism projects in Andalusia, Valencia and the Balearic 


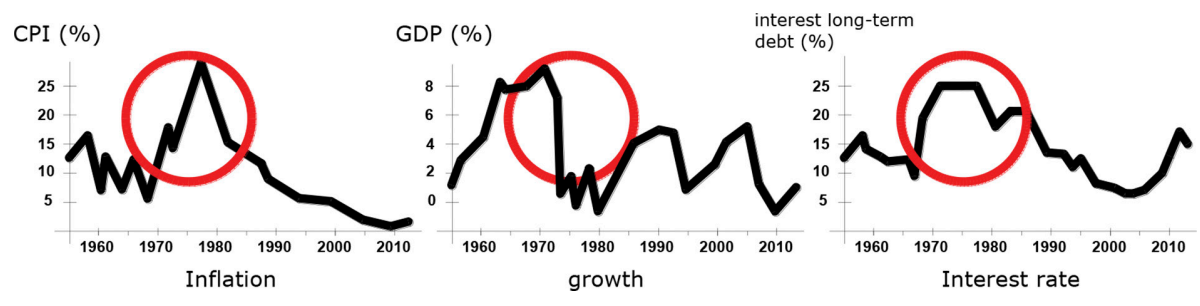

Figure 8: Developments in the economy of Spain from 1950 to 2000.

Islands resulted in several urban pathologies that would not crop up until years later, as the inertia created by the law of an economic production model based on coastal tourism was now unstoppable.

In the case of La Manga, the loss of public funding was lethal in the corporate network upon which Tomas Maestre had cemented his Pharaonic macroproject. This setback, coupled with the loss of income by the fall of sales, forced the developer to pay all small and large contractors in kind, using land parcels resulting from the urbanization of the $20 \mathrm{~km}$ of sand shoal.

This clear example of overflowing, showing how a project of this size sooner or later exceeds the time and money human scale of its creator was finally the seed of a process that ended in chaotic urban hypertrophy a few years later. Small and medium local contractors paid with parcels in a few years became an avid small real estate bourgeoisie. This allied to the new socio-political situation generated a new urbanization process outside Bonet's initial plan. The arrival of democracy in Spain brought administrative decentralization, and implicitly granted planning control to autonomous regions and municipalities. The latter were particularly sensitive to speculative pressures in crisis times; the resorts of the old law of 1962 were perceived by municipalities of the Mediterranean in Spain as a source of wealth and jobs that could not be missed.

This alternative solution to the crisis linked to the predatory vortex of the small developers brought back the dismemberment and annihilation of the structured planning of the 1960s plan. La Manga was then converted, with the complicity of local authorities, into an ungovernable Taifa kingdom and initiated a chaotic urban drift (beyond all legalities in many cases).

An illustrative example of this process is the relationship between the mutation suffered by Bonet's urban plan and the metamorphosis affecting the tourist model derived thereof. The new residential development parcels intended for public equipments and spaces, the overcrowding of the urban plot intended for bulking and the rupture of the model of high-density cores that liberated space by invasive and economic geometries had a direct translation to the tourism model. The high value tourist target established by the LC\&NTIA began a difficult cohabitation with a new more local, less affluent tourist profile seeking not so much a seasonal tourism but second home ownership at a good price. This cohabitation became impossible in a short time. That situation finished with the second kind of tourist dominating and imposed a new profile, which 'cannibalized' the original as an invasive species in an ecosystem.

This phenomenon can be easily transferred into figures. A clear indicator of this behaviour between urban and tourism is the number of beds in La Manga, and more specifically, the relationship between the hotel and non-hotel places. It should be noted that in the late 1970s, the top target population of 60,000 beds for which the initial plan of Bonet was designed had already been reached. This excess was due to the extraordinary growth of the construction of second homes outside the initial planning, thus massifying the ancient sandbar. The hotels went from representing $15 \%$ of the places in the late 1960s to correspond to just $2.6 \%$ in 1988 . While hotel growth stagnated, residential development did not stop, reaching the global figure of 100,000 people in that year (Fig. 9). 

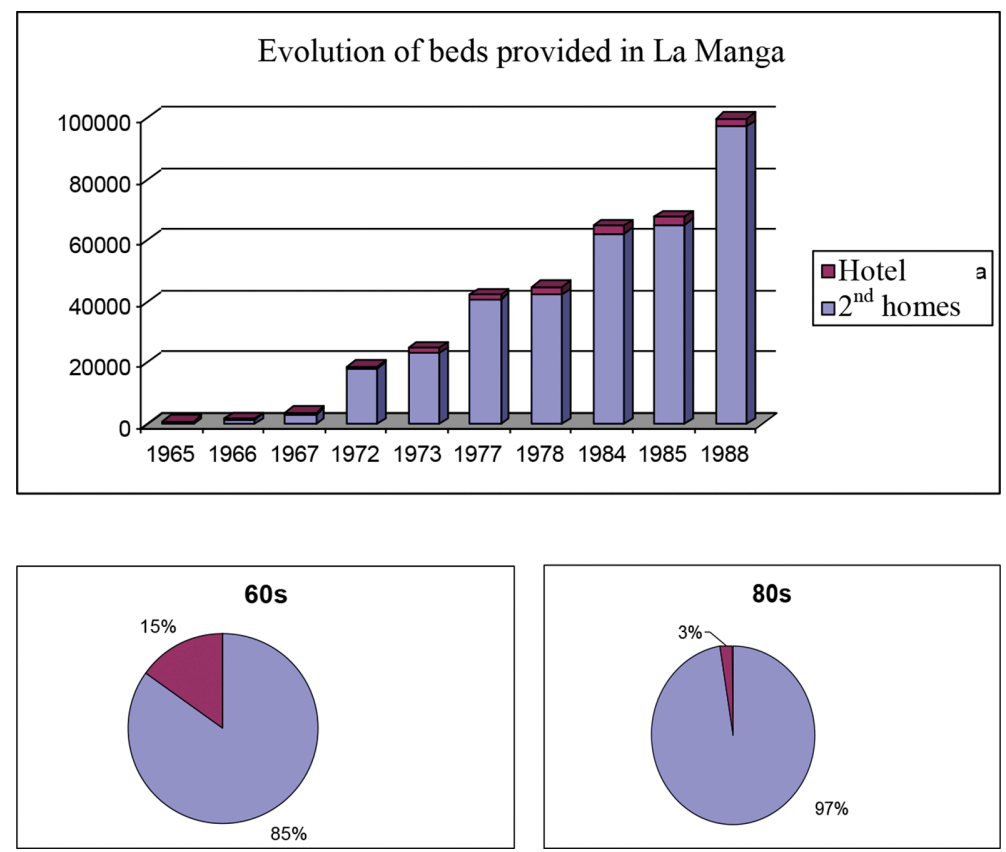

Figure 9: Evolution of hotel beds and second home ones in La Manga from 1965 to 1988. Source: [5].

In 1988, the Autonomous Community of the Region of Murcia (the other administration concerned with the distribution of powers provided for in urban planning Spanish Constitution), decided to stop the chaotic urban inertia that was devouring La Manga. The Spanish legal system allowed the former Autonomous Communities to take control of state powers and planning regulations; however, that doctrine was not legally established until sentence 61/97 of the Constitutional Court 10 years later.

In the 1980s, since the new democratic Constitution of 1978, the responsibility for urban planning was fully assumed by the municipalities and Autonomous Communities, although at first some regional governments were passive in surveillance and control. This motivated strong speculative pressures and severe disturbances and abuse of the law especially in coastal towns, where years ago the LC\&NTIA had begun.

It is at this juncture that in 1988, the regional government decided to assume responsibility for town approval, leveraging state law establishing a 100-m right of way coastal protection on the maritime-terrestrial public domain. This phenomenon, which has been reproduced with varying degrees of controversy in other regions of Spain, acquired special geographical peak intensity in La Manga (Fig. 10).

The Murcia regional government decided to suspend the processing of planning regulations that replaced Bonet's plan and, overtaken by events, it also retroactively repealed hundreds of licenses granted by the council. This situation had the developers up in arms and much of the regional production network based on construction, which interpreted this initiative as the opening of a legal Pandora's box that is assumed as a casus beli for the business promoter accidentally created years before (Fig. 11).

The councils acted in the same direction and posed a conflict of powers, because this loss of autonomy threatened their economic livelihood from tax returns generated by this uncontrolled 


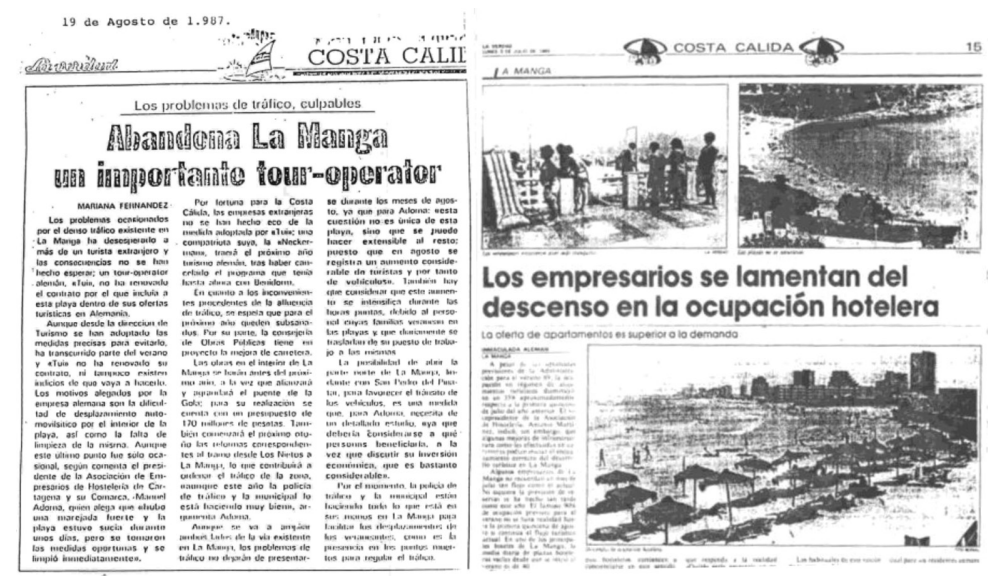

Figure 10: Consequences of the 1980s urban model change. Source: La Verdad newspaper.

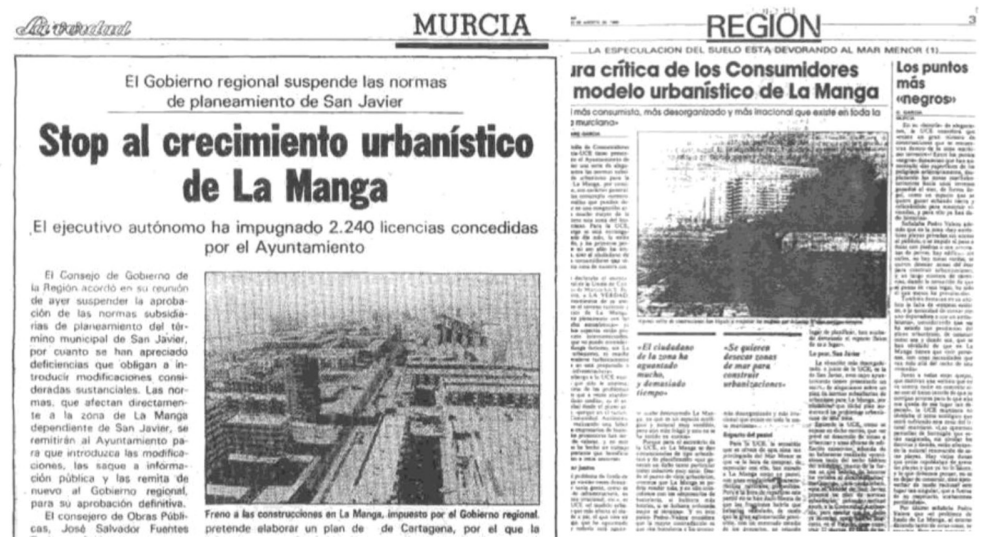

Figure 11: Front page of newspapers on 26.09.1988. Source: La Verdad newspaper.

urban development. The clash was settled in the courts, where municipalities and developers gained a clear victory. Judges retroactively invalidated the actions and declared consolidated urban land use rights granted by the municipalities during the years of empty competence. These rights could, therefore, only be retrieved for the Community by expropriation procedures, whose economic cost led to La Manga and much of the Spanish coast taking an inexorable path of urban overcrowding in exchange for short-term profits. The evolution of La Manga was consolidated this way with an unstoppable massification process, generating a hypertrophied urban structure within a few years by the middle of the 1990s (Fig. 12).

\section{GIS ANALYSIS OF THE RESULTING MODEL PARAMETERS AFTER THE IMPLEMENTATION OF SHORT-TERM URBAN DEVELOPMENT IN THE URBAN PROCESS}

The path taken in the late 1980s culminated in an urban hypertrophy of many enclaves on the Mediterranean coast, with very different purposes emerging in the 1960s through the LC\&NTIA. After several attempts by the state to recoup some of the lost powers, the Constitutional Court 

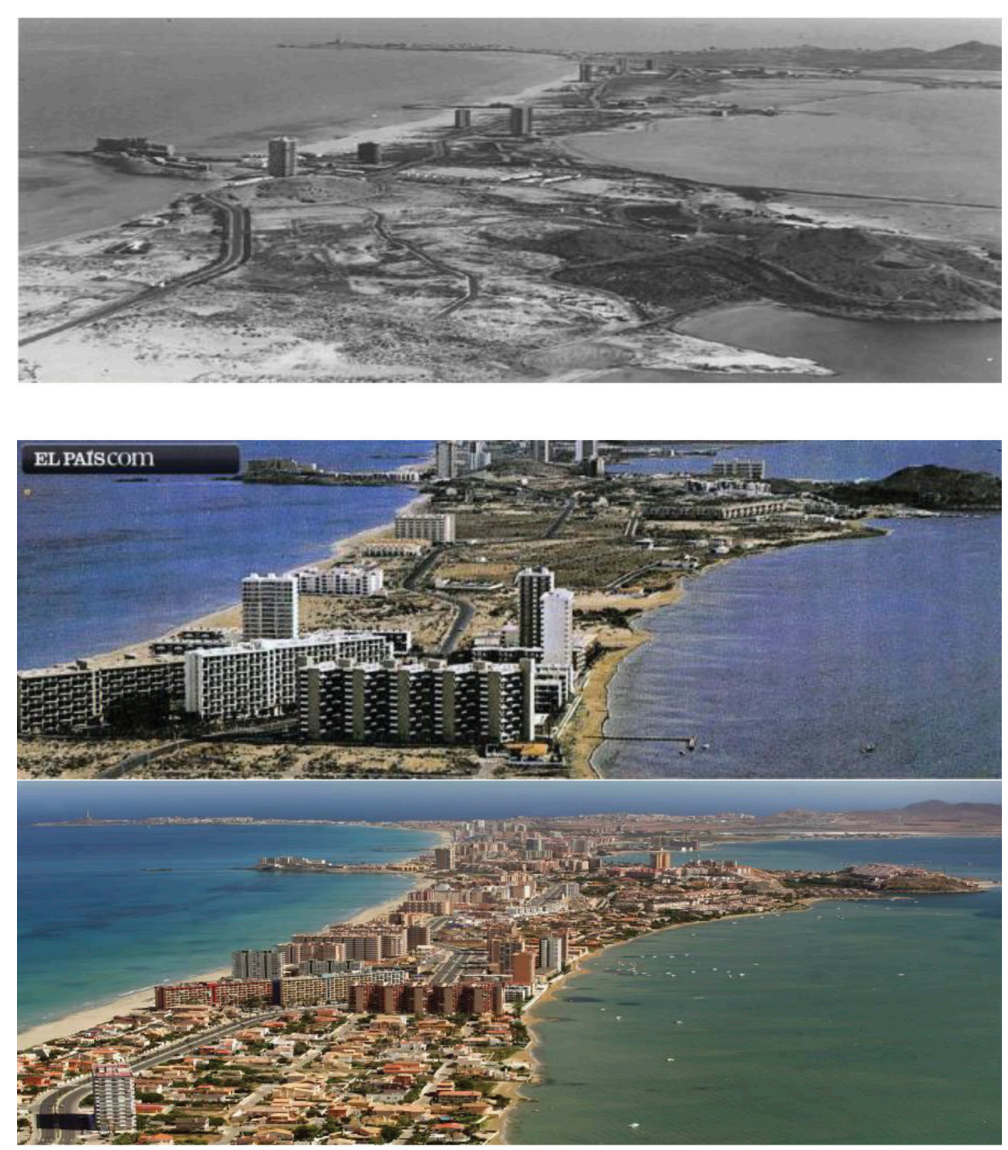

Figure 12: Evolution of La Manga in 1970, 1980 and 1995. Sources: Paisajes Españoles, Diario El País and Murciaturistica S.A.

established a clear legal status on the legislative powers regarding urban planning of State and Autonomous Communities. Autonomous Communities and City Councils share the power, with most of the initiative remaining in the hands of the latter, while the state's role was limited to establishing coastal easements although it was unable to act retroactively on existing buildings, but apply over those made later.

In the case of La Manga, this hypertrophy (currently over 250,000 beds) would lead to an undeniable impoverishment of urban development as a tourism product. This statement is justified by three types of indicators: visual, economic and urban.

First, the visual effects resulting from the urban model change of the late 1970s can be found. The overcrowding process studied is accompanied by other aspects that result in the loss of value as a tourism product. The dissolution of the alternation of low and high density allowing visual release on both sides has given way to a claustrophobic screen effect, due to the implementation of economic typologies and invasive plant (Fig. 13).

Secondly, there are clear urban indicators of the process of impairment, which led to the change of the model. Looking at parameters such as the rate of land occupation or its assessment, they clearly show the elements that motivated the depletion of La Manga as a tourism product [11]. 


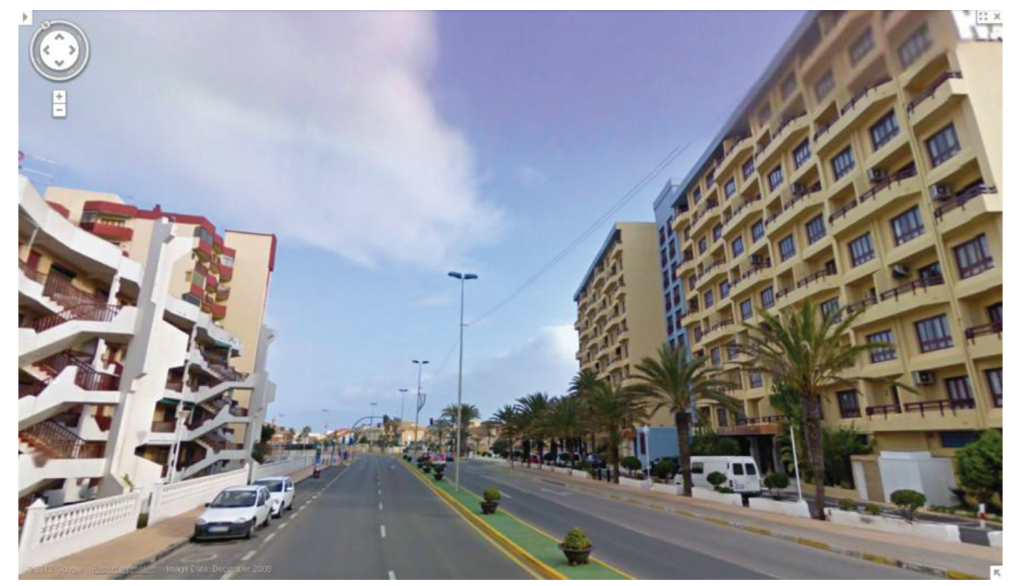

Figure 13: Phenomenon of urban 'screen effect' in La Manga.
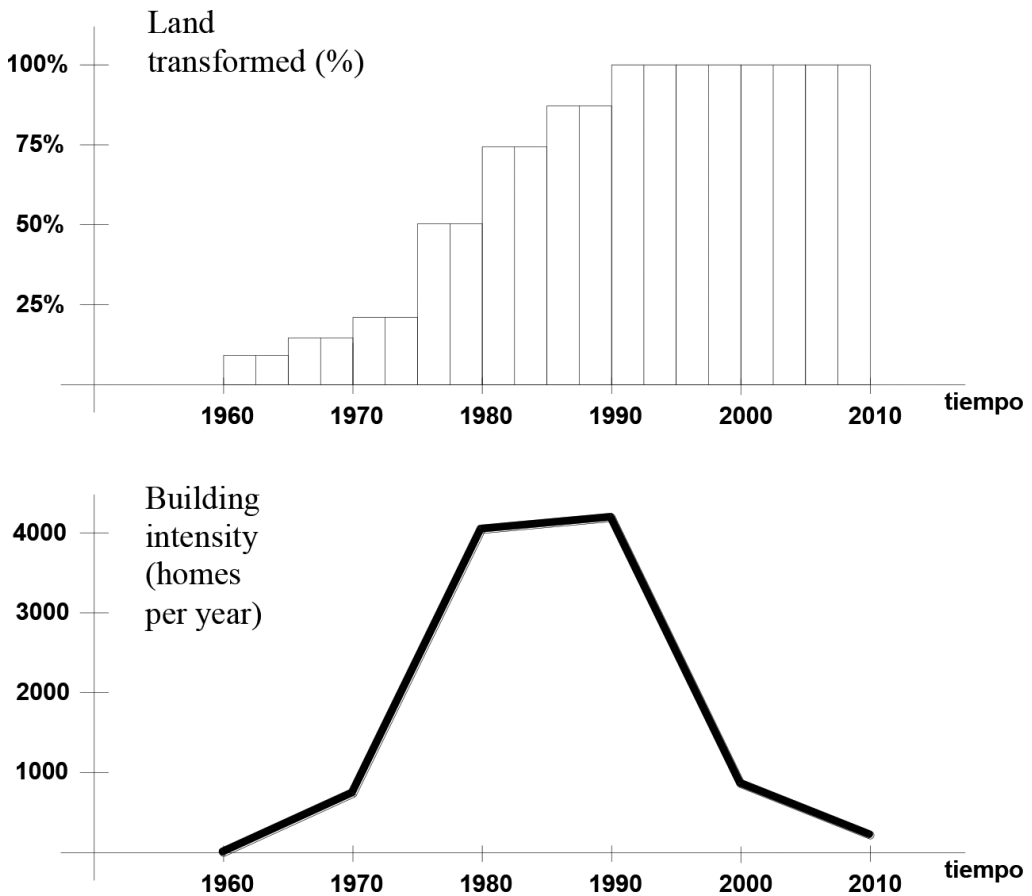

Figure 14: GIS results of consumption of soil and building intensity over time in the southern half of La Manga.

The gradual consumption of soil was frantically accelerated with the distortion of the Bonet Plan from the mid-1970s. However, looking at the amounts in detail and split La Manga (north and south) into two halves, there are important nuances to appreciate. On the one hand, it appears that soil consumption acceleration was concentrated in the years after the distortion of the Bonet Plan, completely saturating the southern half of La Manga, whose overcrowding led to the subsequent fall in construction activity (Fig. 14). 
Observing the evolution of the urbanization through geo-referenced land information systems such as IDERM, the statistical information can be contrasted (Fig. 15). A non-existent or previous urban plot linked to fish farms can be assumed, which acquires a characteristic leisure morphology with the arrival of tourism. This phenomenon is accelerated from the 1980s with the process focusing around that time. It can be seen how intensive land occupation processes alternate with urban replacement phenomenon, with load factors becoming even higher. Urban tissue destined for equipments and green areas is progressively diminished versus the proportion of the residential plot.

If the urban plot generated is analysed qualitatively, saturation processes of building accumulation between 1977 and 1993 are clearly seen, as well as phenomena of redevelopment and replacement of urban tissue that create a dense, chaotic and crowded environment.

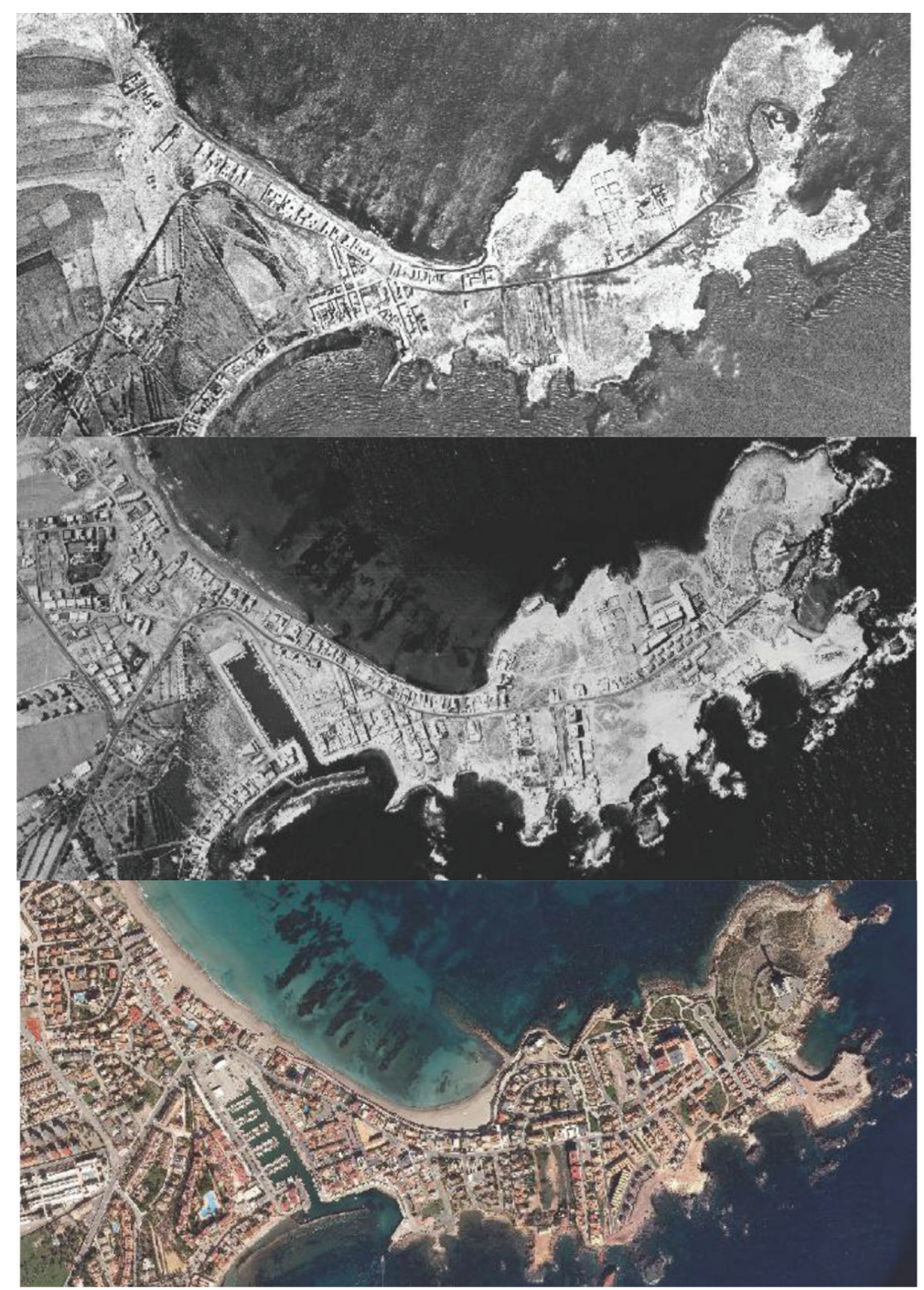

Figure 15: The evolution of La Manga in Cabo de Palos in 1956, 1981 and 2007. Source: IDERM. 
This phenomenon, classified as urban hypertrophy, in the southern section leads to overpopulation during the summer months, a population which the road, hydraulic, electrical, etc. infrastructure is unable to cope with. This creates social and political controversy and the loss of value of La Manga as a tourist destination. These services and infrastructure are oversized during the remaining months of the year, creating an urban model, which is very expensive to maintain and operate (Fig. 16).

In the north, the previous curve moved over time (since the works of urbanization in La Manga followed a chronological sequencing south-north), and compressed in its shape (keeping the concentration of construction activity in the 1980s and early 1990s). However, it is interesting to compare the rate of land use, since the drop in construction activity is not due to soil saturation resulting in overcrowding, as it barely reaches $60 \%$ (Fig. 17).

In practice, this leads to a great deal of urban pathology. On the one hand, the existence of voids generates an incoherent plot often unstructured (Fig. 18). On the other hand, it is difficult to deliver infrastructure and services that have been supplied to the residential plot created (Figs 19 and 20).

Performing the same process through geo-referenced land information systems such as IDERM evident conclusions is reached regarding the results of the speculative urban overcrowding.

The existing urban plot in the south denotes a clear accumulated process of collapse by saturation. The saturation depletes the tourism model that has allowed the process of urbanization. This, therefore, progressively slowed the value of land, with a price decline, which motivates the promoters' need to put more soil to maintain the business profit margin.

This problem is clearly seen in the resulting network of the northern urbanization process, which already reflects the exhaustion that short-term application of parameters in the southern generates in the entire territory from the point of view of the housing sales first, and the plots later.

Modelling the phenomenon in a simple outline of the process shows the existence of a degenerative path model that feeds up to its complete depletion (Fig. 21).

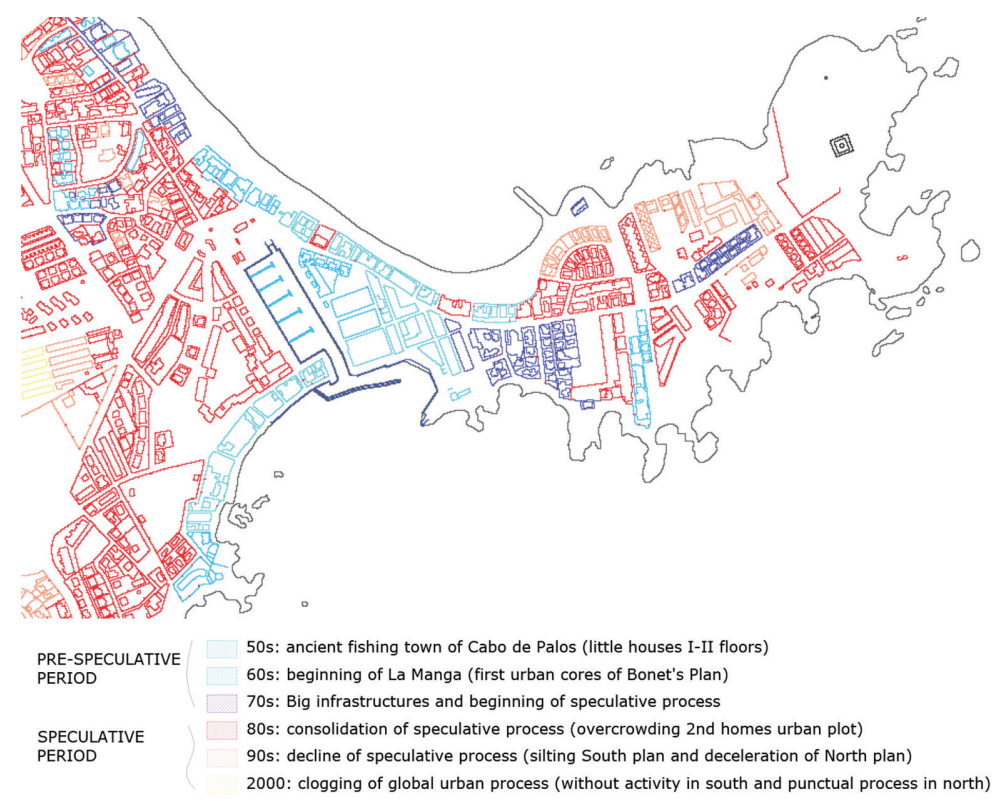

Figure 16: GIS urban timing qualitative analysis of La Manga in Cabo de Palos. Source: [5]. 

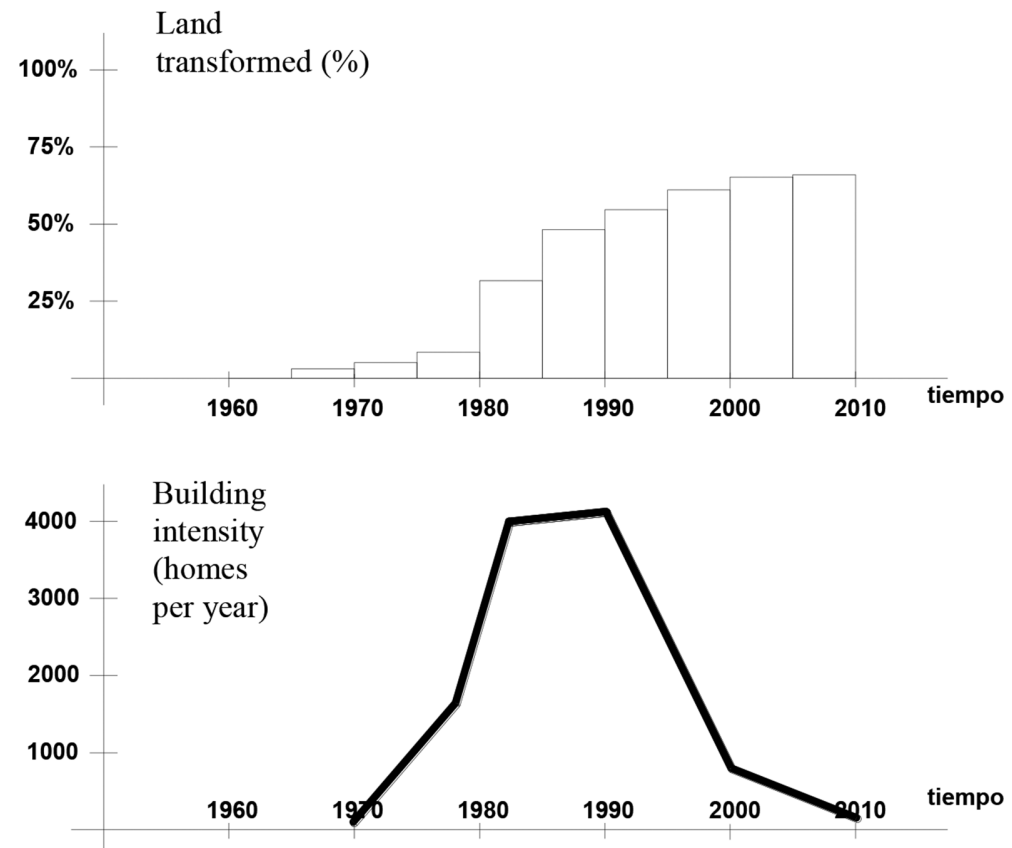

Figure 17: GIS results of temporal evolution of the land surface occupied and the building construction intensity in the northern area of La Manga.

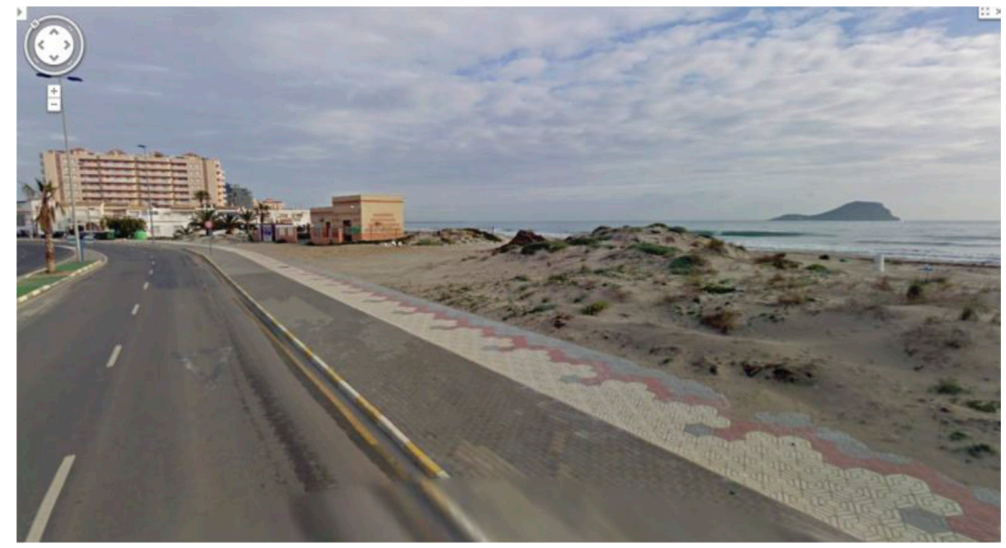

Figure 18: Urban gaps in the northern half of La Manga.

This approach is the third type of socioeconomic indicator of how the change of urbanization process has led to a deterioration of the tourism model impoverishing the value of La Manga. Considering purely economic criteria, it would be questionable whether foreign currency and the economical returns obtained justify the huge public investment made during the 1960s and 1970s. If social variables (employment generation, local wealth, indirect generation of production, etc.) are added to this equation, then the question becomes even more controversial [3]. 


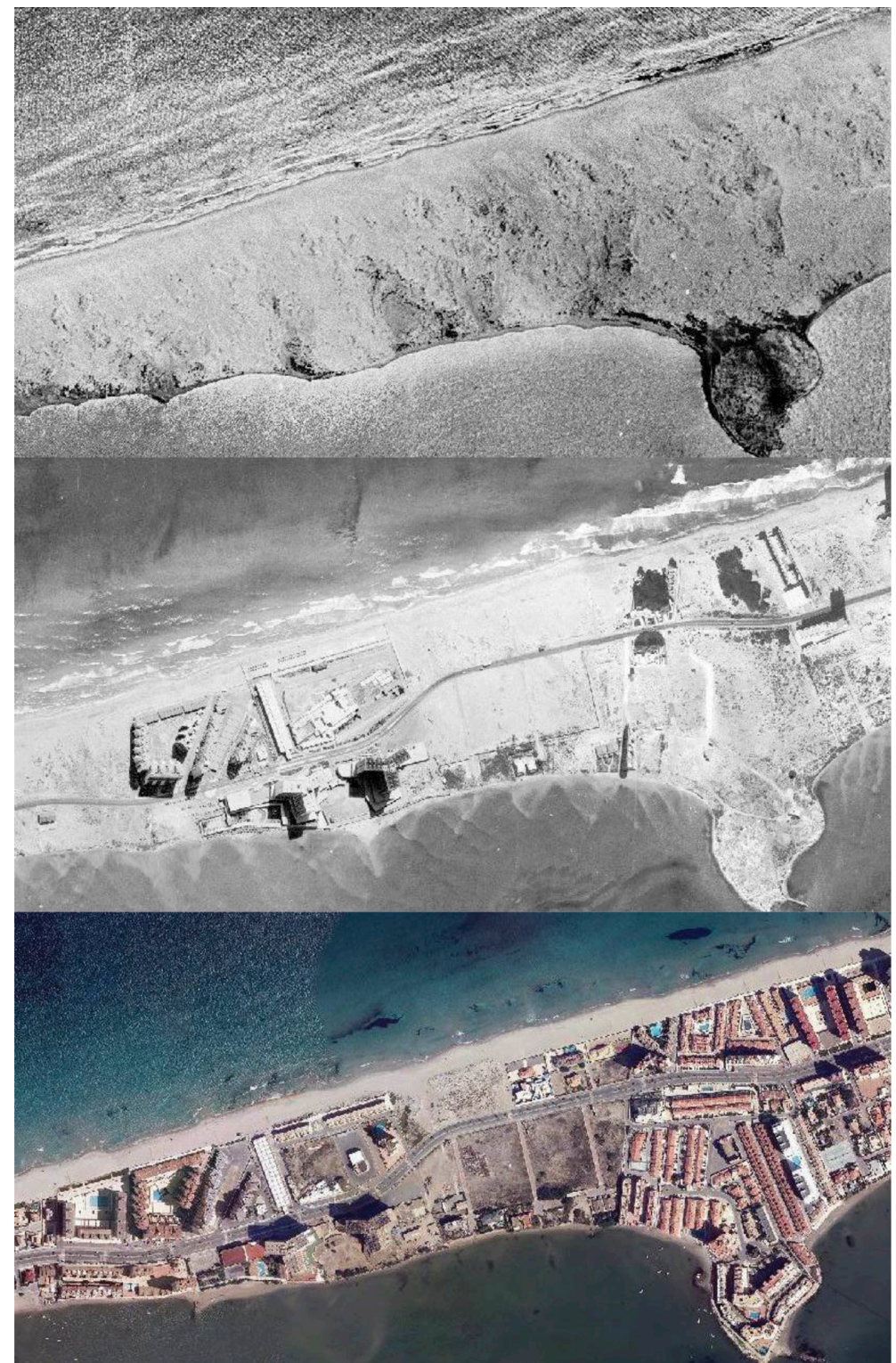

Figure 19: Evolution of La Manga in a section of the northern half in 1956, 1981 and 2007. Source: IDERM.

This coastal macroproject's category has two problems, as the analysis not only has to evaluate the cost of the investment, but high maintenance costs must also be added. This maintenance also faces additional difficulties such as the strong seasonality of demand, which requires significant investment in infrastructure during the summer months to maintain a level of service, which is not amortized over the rest of the year in which the city becomes a big mass of empty buildings. 


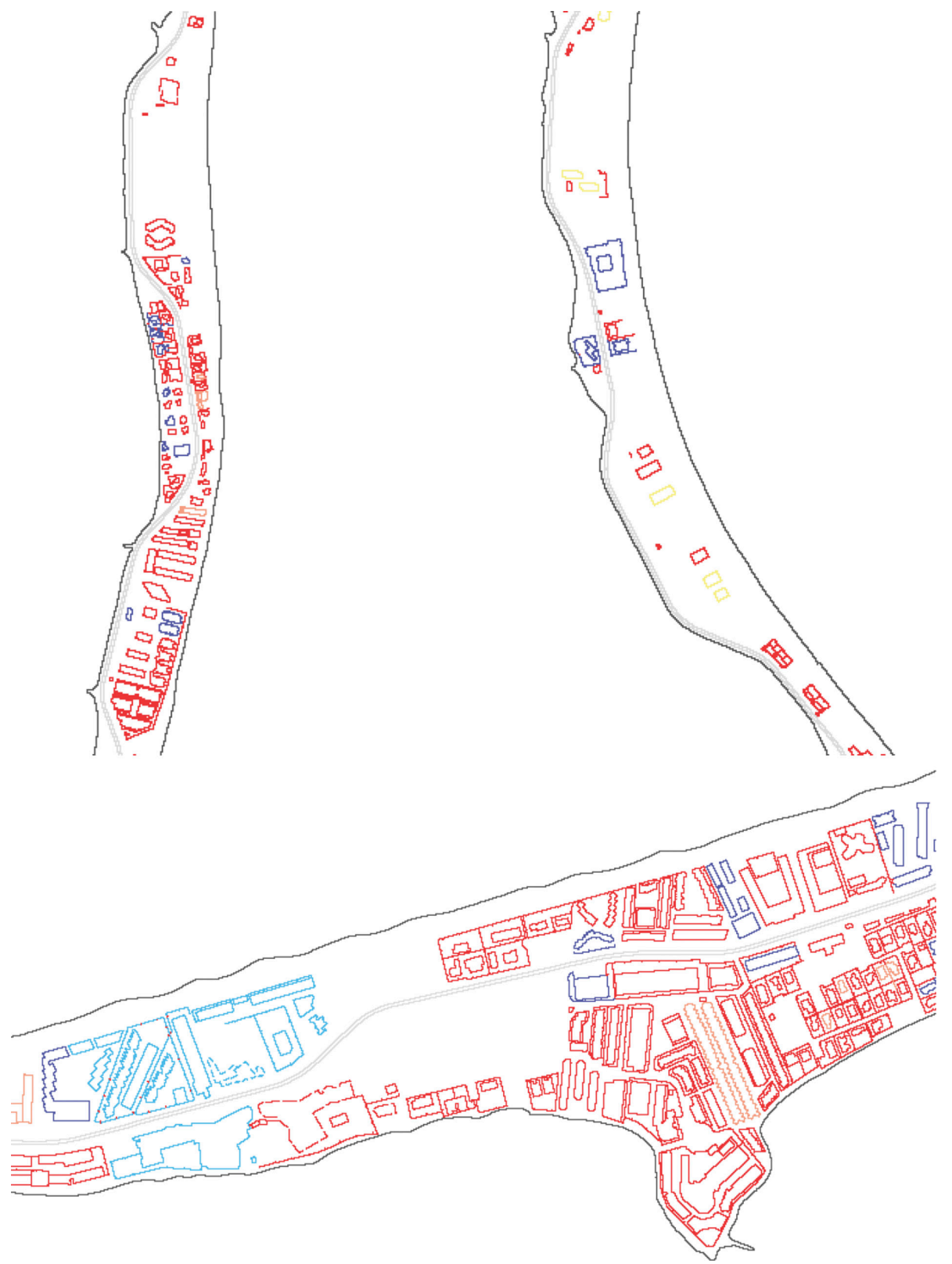

Figure 20: GIS urban timing qualitative analysis of La Manga in different north sections. Source: [5].

In La Manga, the change of urban model accentuated this degeneration into a complex problem, which is certainly unsustainable. The removal of the urban cores and the hierarchical structure collapsed the road traffic management, a problem that stems from overcrowding. The strong population growth was not followed by the development of infrastructure (the Bonet Plan was designed to manage a population four times lower), causing the flight of customers of the highest demand that 


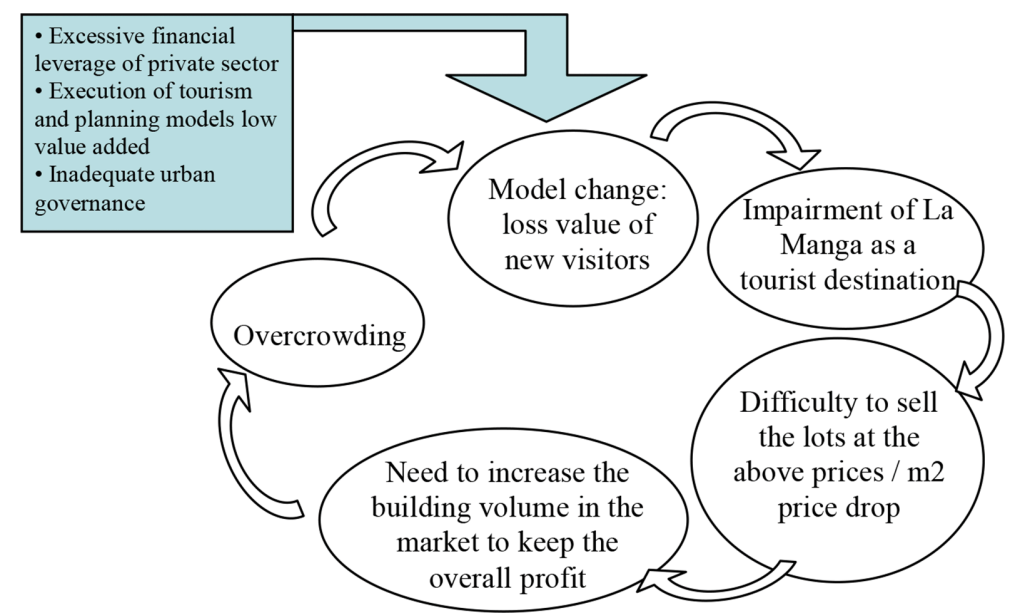

Figure 21: Schematic model of speculative process of feedback overcrowding of La Manga.

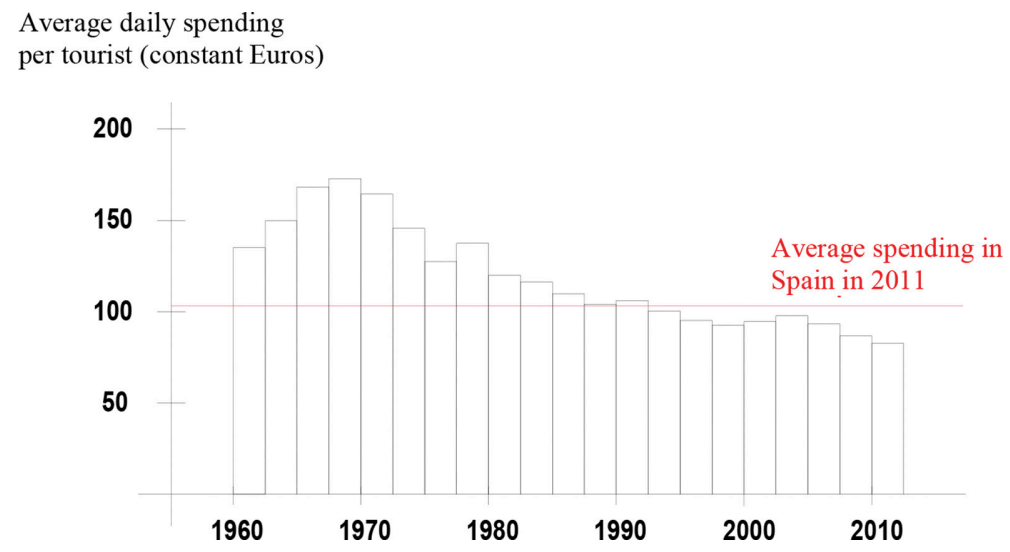

Figure 22: Evolution in La Manga in average spending per tourist since its inception. Source: [5].

brought the higher profit margins. In this sense, using the methodology of the evaluation of the cost to future urban projects as a tourism product [4], it is observed that a higher volume of tourists does not necessarily imply higher economic or social profits. An illustrative parameter in this sense is the average daily return generated by each tourist. This value has been suffering a gradual fall from the 1970s from being a value well above the national average to below it [5] (Fig. 22).

\section{EXTRAPOLATION TO THE REST OF THE SPANISH COAST: THE REPEATING PATTERN IN THE CURRENT SCENARIO.}

The case of La Manga is not an isolated element in the urban development of the Spanish coast. Many of the enclaves created by the 1962 law are now tourist cities suffering urban pathologies or similar situations to what happened in La Manga (see for example [6-10].

In La Manga, there has been a clear consequence of the loss of land value, moving from being an expensive product with a high speculative component to a product with a limited market demand. 
This movement is mimicked in many other parts of the Spanish Mediterranean coast [2]. This effect is heightened on the Mediterranean coast, which, as shown in Fig. 23, typically represented more than $40 \%$ of the homes built each year. A valley can also be seen in the early 1990s and a sharp drop from 2007 (the collapse in the value of coastal property has remained in Spain since 2007). In the case of La Manga, this effect is attenuated, not by a better resistance to the crisis, but because the impairment as a real estate asset had already been anticipated in the previous decade for the above reasons.

However, errors related to urban development based on short-term criteria are not exclusive of the past. As a result of the economic crisis ravaging Spain during the last 5 years, several urban macroprojects of a questionable economic viability are now beginning to emerge, demanding greater flexibility in legislation on the coast or in other fields of law for its implementation. In this sense, there is an extensive catalogue of cases of this phenomenon developing today on the Spanish coast.

A clear example of this problem in the urban area is the resort of Marina d'Or on the Castellon coastline (east coast of Spain), which aims to accommodate more than 220,000 visitors in 38 million square meters (Figs 24 and 25).

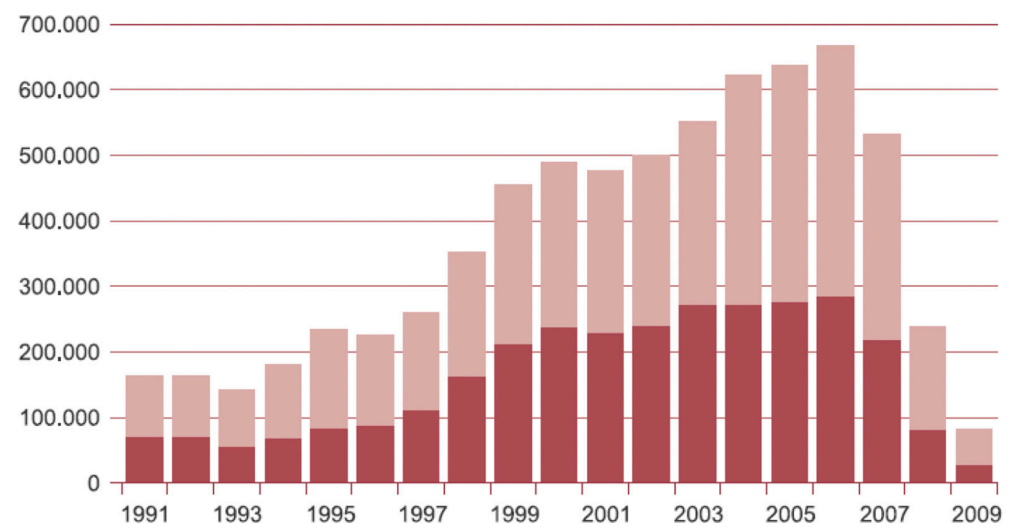

Figure 23: Number of houses finished each year in Spain and Spanish Mediterranean coastal. Origin: National Statistics Institute of Spain [2].

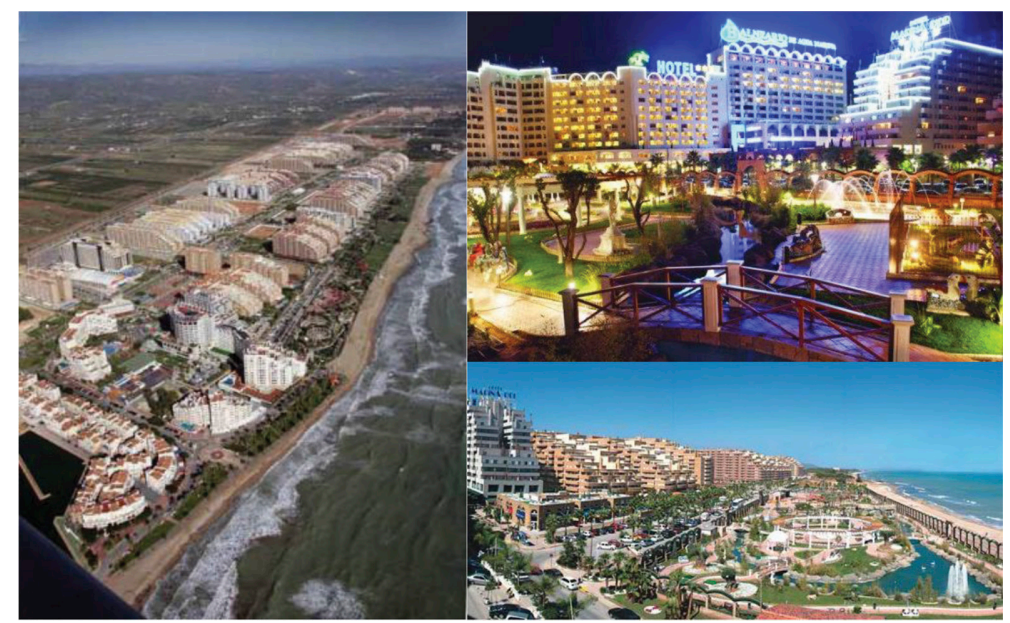

Figure 24: Complex Marina d'Or. Source: Marina d'Or, Inc. 


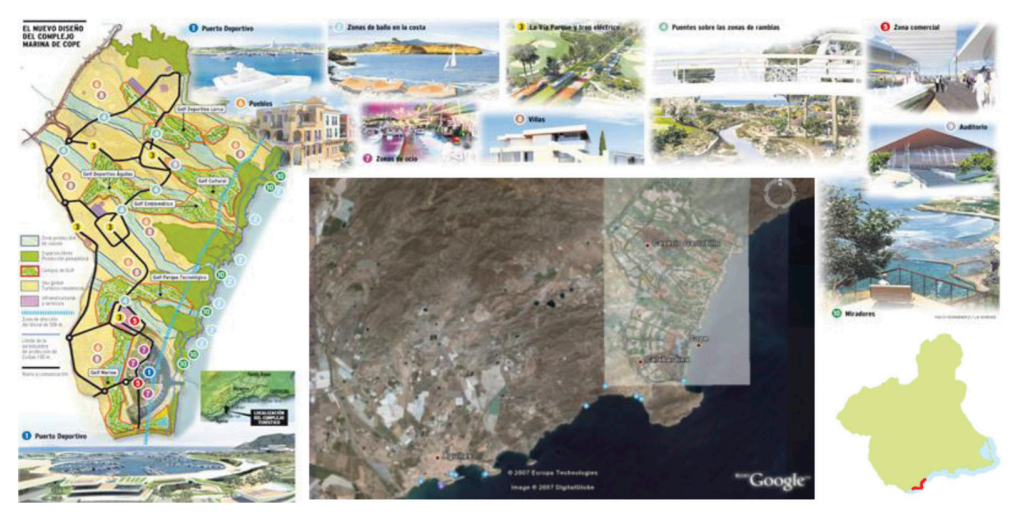

Figure 25: Marina Cope project on the coast of Murcia. Source: [5].

Another example of this revival in coastal urbanization would be the case of Marina Cope in the Region of Murcia. With the urbanization concentration around La Manga and the Mar Menor during the decade of the 1960s, 1970s, 1980s and 1990s, the south coastal territory of the region remained unchanged. This fact nowadays favours the existence of large areas of coastline with a strong appeal to developers because of its attractive natural conditions.

One of these is the large dock of Marina de Cope (Fig. 25), which will offer more than 9000 homes and 20,000 hotel places around a large marina with golf courses. This project has sparked numerous legal disputes due to be settled now in a regulated environment area as a space protected by the Natura 2000 network $[12,13]$.

All these projects are framed in a legal and political context of implementing strategic action figures in regional urban laws and flexibility in national legislation to ensure viability of the coasts. These cases are, therefore, not isolated elements, but clear examples expressing a trend that has strong similarities with the socioeconomic boundary conditions of crisis that led to the creation of regulations that supported projects such as La Manga in the 1960s [14-16].

The case of La Manga is not, therefore, a sufficiently representative sample to take general conclusions that could be extended to all the Spanish coastal urbanization casuistry. However, it does represent an instructive example of how it is necessary to reflect with an urban social and economic long-term analysis for important projects on the Mediterranean coastline.

\section{PROPOSALS AND CHALLENGES FOR THE FUTURE}

Developing solutions to the problem of La Manga has been a question long debated by experts and urban planners over the past decades. The proposals have ranged from more drastic solutions such as the reversal of private land or reducing the buildability to powerful investment projects to make it more attractive to tourists.

The first proposals had many problems from a legal point of view. As noted above, in 1988, the regional government sought to capitalize on the entry into force of the National Coastal Law to curb the chaotic urban inertia of La Manga. This situation was totally rejected by the real estate business establishment, and ended up in the courts, which agreed with the entrepreneurs. Furthermore, recent attempts to reduce the buildable area of some sectors of urban planning pending construction have had the same results in the courts.

Legal rulings basically set out that once planning permission to build has been granted to landowners, the only way to reduce these already acquired rights is by expropriation. This solution, due 
to its huge economic cost, is clearly unaffordable in coastal environments such as La Manga. We are, therefore, in areas where planning has already exhausted its possibilities (in the case of La Manga all the land are urban or developable according to the General Urban Plan) and the leeway from the planning point of view is limited by legal constraints.

Another highly debated field of solutions has been the need to revalue La Manga as a tourist product through investment projects. Private initiative proposals have been raised that have been disastrous due to their lack of business accuracy (Carmichael case in the mid-1990s, [17]), as well as public initiatives that are currently stalled.

In the case of the latter, two actions can be highlighted. First, incentives have been generated in urban areas pending to be built on to change the residential use of second homes to tertiary hotels. This is, therefore, to seek mechanisms to redirect the tourist offer to a product with less seasonality and higher value to decrease saturation and increase revenues. This way remains to be explored due to the lack of interest or inability of entrepreneurs to act in the current context of economic crisis in Spain. Secondly, there is the generation of new tourism products in La Manga such as the creation of new activities to attract new and different tourists. A typical case in this field is the PuertoMayor project [18], a marina for large ships intended to bring in high-spending tourists or travellers from cruises. This project, for example, remains paralysed by various legal controversies and uncertainties about its urban and environmental viability.

The solution to urban pathologies in urbanistically depleted environments such as La Manga must, therefore, come linked to this second approach [19]. However, it is clear that the main objective of the investigations as presented in this article does not have to focus on presenting particular solutions to particular cases. The real challenge of this research is to be able to analyse, identify and explain the causes and consequences of such complex and interesting cases as La Manga. This is the only way to try to learn from past mistakes and thus avoid repeating them in the future, as may be the case in Spain as well as in other countries of the world in a high-growth phase.

\section{CONCLUSIONS}

The data analysed lead to a series of conclusions that, without being definitive or generalizable, serve as instructive elements for future junctures with macro urban projects in the coastal environment:

1. The development of the case clearly exposes that an urban project such as La Manga can be originally correct, but can lead to a subsequent disastrous reality if it is not implemented with the required control mechanisms and long-term regulation. These kinds of very longstanding macroprojects must, therefore, be limited to environments where the boundary conditions provide a reliable economic stability, and guaranteed and proper urban governance.

2. From the urban management viewpoint, deregulation or absence of urban control of the process easily leads to overcrowding. This model, which may lead to some kind of short-term benefit, finally drives to a loss in the value of the tourist product in the long-term economic field and generates a tendency to urban hypertrophy.

3. From the socioeconomic point of view, there are strong interrelationships between the urban development model of the coastal city and its configuration as a mass tourism product. A change in the former on the above premises eventually leads to severe alterations in the second, assuming the loss of the profitability of the tourism product. This return is possible to evaluate with objective technical parameters with sufficient historical perspective for processes that attain 50 years. In this field, processes based on excessive public or private financial leverage eventually suffer from an economic dependence that makes the project unsustainable in the long term. 


\section{REFERENCES}

[1] Galiana, L. \& Barrado, D., Los centros de interés turístico nacional y el despegue del turismo de masas en España. Investigaciones Geográficas, 39, pp. 73-93, 2006. ISSN: 0213-4691. doi: http://dx.doi.org/10.14198/ingeo2006.39.04

[2] Rullán Salamanca, O., La regulación del crecimiento urbanístico en el litoral mediterráneo español. Revista Ciudad y Territorio, 168, pp. 279-298, 2011.

[3] López-Morell, M., Pedreño, A. \& Baños, P., Génesis y trayectorias del desarrollo turístico del entorno del Mar Menor, VIII Congreso de la AEHE, 2006.

[4] Steinitz, C., Environmental Planning for Communities. Technology Transfer and Support Division Office of Research and Development, United States Environmental Protection Agency, Cincinnati, OH, 2000.

[5] García-Ayllón, S., En los procesos de urbanización del mediterráneo: el caso La Manga, $\mathrm{PhD}$ Thesis, Polytechnic University of Valencia, Spain, 2013.

[6] Miralles i Garcia, J.L. \& García-Ayllón, S., The economic sustainability in urban planning: case La Manga. WIT Transactions on Ecology and The Environment, 173, pp. 379-389, 2013. doi: http://dx.doi.org/10.2495/sdp130231

[7] Miralles i Garcia, J.L., Real estate crisis and sustainability in Spain. WIT Transactions on Ecology and the Environment, 150, pp. 123-133, 2011. doi: http://dx.doi.org/10.2495/sdp110111

[8] Gaja i Díaz, F., Deconstruction. La desconfiguración del litoral mediterraneo español, Universitat Politècnica de València: Valencia, 2012.

[9] Miralles i Garcia, J.L., The introduction of the sustainability in the procedures regulated for urban planning: the case of the last act on urbanism, territory and landscape in the Valencian Community (Spain). WIT Transactions on Ecology and the Environment, 102, pp. 505-513, 2007. doi: http://dx.doi.org/10.2495/sdp070482

[10] Miralles i Garcia, J.L., Sustainability regulations in urban planning: the experience of the Autonomous Community of Valencia (Spain). WIT Transactions on Ecology and the Environment, 120, pp. 3-12, 2009. doi: http://dx.doi.org/10.2495/sdp090011

[11] Stiglitz, J.E., The Stiglitz Report: Reforming the International Monetary and Financial Systems in the Wake of the Global Crisis. The New Press, 2010.

[12] Miralles i Garcia, J.L., The planning of peri-urban agricultural areas: the case of 'L'Horta de València”, Proceedings of 18th International Conference on Urban Planning, Regional Development and Information Society, eds. M. Schrenk, V.V. Popovich, P. Zeile \& P. Elisei, CORP: Roma, pp. 953-962, 2013.

[13] Miralles i Garcia, J.L., Díaz Aguirre, S. \& Altur Grau, V.J., Environmental impact on the Mediterranean Spanish coast produced by the latest process of urban development. WIT Transactions on Ecology and the Environment, 155, pp. 379-389, 2012. doi: http://dx.doi. org/10.2495/sc120321

[14] Martínez Pagés, J. \& Ángel Maza, L., Análisis del precio de la vivienda en España, Banco de España: Madrid, 2003.

[15] Colaninno, N., Cerda, J. \& Roca, J., Spatial patterns of land use: morphology and demography, in a dynamic evaluation of urban sprawl phenomena along the Spanish Mediterranean coast. 51st ERSA Congress Barcelona: Processes of Urbanization along the European Coastal Areas, 2011.

[16] Gaja i Díaz, F., El "tsunami urbanizador" en el litoral mediterráneo. El ciclo de hiperproducción inmobiliaria 1996-2006, Scripta Nova, Revista Electrónica de Geografía y Ciencias Sociales, XII(270), 2008. 
[17] García Sánchez, A.; Artal Tur, A. \& Ramos Parreño, J.M., El turismo del Mar Menor: predominio de la segunda residencia. Cuadernos de turismo, 8, pp. 14-28, 2002, ISSN 1139-78.

[18] Miralles i Garcia, J.L. \& García-Ayllón, S., The urban metamorphosis of La Manga and the "mediterraneanisation" process of the Mar Menor (Spain). WIT Transactions on Ecology and the Environment, 169, pp. 53-64, 2013. doi: http://dx.doi.org/10.2495/cp130051

[19] García-Ayllón, S. \& Miralles i Garcia, J.L., Feedback between tourism model and urban planning in La Manga, a mass tourist destination in the Spanish coast. WIT Transactions on Ecology and The Environment, 187, pp. 339-350, 2014. doi: http://dx.doi.org/10.2495/st140261 